\title{
Safeguarding global plant health: the rise of sentinels
}

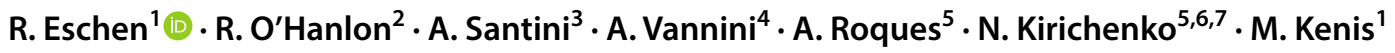

Received: 31 January 2018 / Revised: 20 August 2018 / Accepted: 28 August 2018 / Published online: 4 September 2018

(c) The Author(s) 2018

\begin{abstract}
The number of alien plant pests and pathogens is rapidly increasing in many countries as a result of increasing trade, particularly the trade in living plants. Sentinel plantings in exporting countries to detect arthropod pests and agents of diseases prior to introduction provide information about the likelihood of introduction and the potential impact on plants native to the importing country. Such plantings can consist of species that are native to exporting or importing countries ("in-patria" and "ex-patria" plantings). In-patria plantings consist of young woody plants of species that are commonly exported and can be used to identify pests that may be introduced to new countries via the trade in live plants. Ex-patria plantings consist of exotic young or mature woody plants and surveys may provide information about potential impacts of pests if these were to become established in a new country. We discuss the methods and benefits of this powerful tool and list examples of studies that highlight the large number of unknown organisms and pest-host relationships that can be detected. The usefulness of sentinel plantings is illustrated using examples of arthropod pests and fungal pathogens of European and Asian tree species that were identified in sentinel studies in China and the Asian Russia.
\end{abstract}

Keywords Woody plants $\cdot$ Exotic pests and pathogens $\cdot$ Early warning

\section{Key message}

- Many exotic plant pests and pathogens are unknown prior to their establishment, making prevention and management difficult.

Communicated by D. Rassati.

Special Issue on Invasive Pests of Forests and Urban Trees.

R. Eschen

r.eschen@cabi.org

1 CABI, Delémont, Switzerland

2 Agri-Food and Biosciences Institute, Newforge Lane, Belfast, Northern Ireland, UK

3 Institute for Sustainable Plant Protection CNR, Sesto Fiorentino, FI, Italy

4 DIBAF, University of Tuscia, Viterbo, Italy

5 Institut National de la Recherche Agronomique, Orléans, France

6 Sukachev Institute of Forest SB RAS, Krasnoyarsk, Russia

7 Siberian Federal University, Krasnoyarsk, Russia
- Sentinel plantings to detect pests and pathogens prior to introduction provide information about the likelihood of introduction and the potential impact on plants native to the importing country.

- This paper discusses the different types of sentinel plantings based on the native range and age of the plants, their purpose, limitations and benefits.

- Summarised results from published studies illustrate the benefits of sentinel plantings.

\section{Introduction}

Alien arthropod pests and pathogens (hereafter "pests") of woody plants are causing significant ecological and economic damage to forests worldwide (Holmes et al. 2009). The increasing number of new alien pests of woody plants in many parts of the world (Liebhold et al. 2012; Santini et al. 2013), although not equal across countries and taxa (Aukema et al. 2010; Brockerhoff and Liebhold 2017), coincides with the rapid increase in the volume and diversity of intercontinental trade in plants for planting (Kenis et al. 2007; Liebhold et al. 2012; Roques et al. 2009; Santini et al. 2013). The large number of plants traded and the 
inconspicuousness of many pests, in particular microbial pathogens, highlight the need to mitigate the risk associated with this pathway. Even assiduous inspection will not completely prevent the introduction of new pests because they may be difficult to see with the naked eye or they can remain latent in apparently healthy plant tissues (Migliorini et al. 2015; Meurisse et al. 2018). Research has shown that many plant pests have been established in a country for several years or decades prior to detection (Liebhold and Tobin 2006; Poland and McCullough 2006). This detection time lag, as well as the additional delay between the detection and reporting of establishment (often $>2$ years, see e.g. Smith et al. 2018), further limits the chance of eradication.

International and national phytosanitary regulations stipulate measures aimed at managing the risk of introducing harmful organisms, often following pest-risk analysis and based on scientific evidence (Eschen et al. 2015a). A prerequisite is, however, that the identity and potential impact of the pest are known. This information is usually unavailable, as many of the most damaging non-native pests of forest and ornamental woody plants were previously unknown to science, or unknown to be harmful in their native ranges (e.g. Carter 1989) or not recorded as invaders in regions outside the native one (Seebens et al. 2018). Recent examples include the emerald ash borer, Agrilus planipennis (Coleoptera: Buprestidae), that invaded the USA where it kills North American ashes (Herms and McCullough 2014), and the lime leafminer, Phyllonorycter issikii (Lepidoptera: Gracillariidae), an East Asian insect that has spread across most of Europe and Russia in the last three decades and become a pest of lime trees (Kirichenko et al. 2017). Several examples exist also among pathogens (e.g. Werres et al. 2001; Santini et al. 2013; Gross et al. 2014). In all these cases, no measures to prevent their entry and establishment had been taken before their first introduction (Eschen et al. 2015b), indicating that the current phytosanitary system is not effective at timely identification of new invaders.

\section{Sentinel plants and trap trees}

Sentinel plants can be defined as plants present in the vicinity of high-risk sites or in urban areas that are inspected at regular intervals for signs and symptoms of pest attack (Wylie et al. 2008; Paap et al. 2017). Inspections of sentinel plants represent one of several post-border surveillance activities that can be carried out to detect recently introduced non-native species soon after its arrival, increasing chances of eradication and control (Poland and Rassati 2018). On occasions, sentinel plants allow to denote novel pest-host associations, as illustrated by Sweeney et al. (2012), who first recorded the European beech flea weevil, Orchestes fagi (Coleoptera: Curculionidae), as a pest of American beech.
Trap trees can be instead defined as trees treated by girdling, wounding, or with semiochemicals to render them attractive to a given target species (e.g. McCullough et al. 2009; Fan et al. 2018) and have been demonstrated to be particularly useful to monitor the spread of pests (e.g. Poland and McCullough 2006; Marshall et al. 2009; Dodds and Miller 2010). Nonetheless, both approaches are used after a nonnative species has been introduced in a country, when it can be already difficult or expensive to eradicate (e.g. Brockerhoff et al. 2010). Detection and identification of pests prior to their arrival or establishment in a country should therefore be a priority and may allow the development of preventative and invasion mitigation measures.

\section{The sentinel planting concept}

Sentinel plantings differ from sentinel plants in that they are located in the country of origin of the pests. They provide an earlier warning by identifying harmful organisms in regions of origin before they are introduced and become established elsewhere (Fagan et al. 2008; Britton et al. 2010; Barham et al. 2016). Sentinel plantings can be categorised into two main approaches with different concepts and objectives (Table 1; Fig. 1). "In-patria" sentinel plantings (or "sentinel nurseries", sensu Vettraino et al. 2017), are plantings of woody plants in their native range, either in nurseries or in open fields. Surveys and identification of native-to-native pest-host associations in these plantations provide information on the harmful organisms that may be transported with traded plants (i.e. likelihood of introduction or entry into the plants for planting pathway). In-patria plantings provide an additional (more convenient) approach to detect native pests on native plants in an "artificial" setup that complements the traditional approach of recording these associations in the natural environment. The in-patria approach aims to identify the entire range of pests that may be introduced with traded plants, because damage observed on plants in in-patria plantings may not be representative of the damage to native tree species in the importing country. Hence, a general difficulty in detecting harmful organisms when in-patria plantings are used is the weakness or even absence of symptoms, and a potentially harmful organism may thus not be perceived as a risk or could even pass unnoticed (Vettraino et al. 2017).

By contrast, "ex-patria" plantings (or "sentinel plantations" sensu Roques et al. 2015) are plantations of woody plants outside their native range. These can be existing collections of woody plants in botanic gardens or young woody plants planted for this purpose (Fig. 1). Surveys and identification of novel host associations with pests in these plantings provide information about the potential impact of these organisms in the importing country if they were introduced. 
Table 1 Comparison of the two approaches of sentinel plantings in terms of concept, objectives, benefits and drawbacks

\begin{tabular}{|c|c|c|}
\hline & In-patria & Ex-patria \\
\hline Concept & $\begin{array}{l}\text { Exposure of traded native woody plants that have } \\
\text { not been treated with pesticides, to pests in the } \\
\text { exporting country }\end{array}$ & $\begin{array}{l}\text { Exposure of exotic woody plants that have not been } \\
\text { treated with pesticides }{ }^{\mathrm{a}} \text {, to observe damage by } \\
\text { pests in the exporting country }\end{array}$ \\
\hline Origin of trees & Native to exporting country (native woody plants) & Native to importing country (exotic woody plants) \\
\hline Location & Plantation established as sentinel planting & $\begin{array}{l}\text { Botanic gardens established for other purposes, or } \\
\text { plantation established as sentinel planting }\end{array}$ \\
\hline Objectives & $\begin{array}{l}\text { New pest-host associations detected to assess the } \\
\text { likelihood of introduction of pests }\end{array}$ & $\begin{array}{l}\text { Damage detected, as indication of potential impact } \\
\text { of exotic pests on plants in case they are intro- } \\
\text { duced to the region of origin of the plant }\end{array}$ \\
\hline \multirow[t]{6}{*}{ Benefits and drawbacks (young trees) } & Few regulations apply & Potentially many regulations apply \\
\hline & Relatively inexpensive to set up & $\begin{array}{l}\text { Potentially expensive to set up (importation or } \\
\text { grown from propagation material such as seeds) }\end{array}$ \\
\hline & Primarily foliage pests detected & \\
\hline & Possibility of planting many trees & Primarily foliage pests detected \\
\hline & Environmental effects less measurable & Possibility of planting many trees \\
\hline & $\begin{array}{l}\text { Difficult to detect harmful organisms due to the } \\
\text { absence of damage or symptoms }\end{array}$ & Environmental effects less measurable \\
\hline \multirow[t]{6}{*}{ Benefits and drawbacks (mature trees) } & $\begin{array}{l}\text { Not applicable-in most cases only young woody } \\
\text { plants are traded }\end{array}$ & Few regulations apply \\
\hline & & $\begin{array}{l}\text { Inexpensive to set up as many sites already exist } \\
\text { (e.g. botanic gardens) }\end{array}$ \\
\hline & & Also xylophagous pests detected \\
\hline & & $\begin{array}{l}\text { Small sample size (often only few individual trees } \\
\text { at each site, planted earlier for other purposes) }\end{array}$ \\
\hline & & $\begin{array}{l}\text { Environmental effects better measurable over the } \\
\text { long term }\end{array}$ \\
\hline & & $\begin{array}{l}\text { It is possible to detect a larger variety of pests if } \\
\text { plants from different origins have been planted }\end{array}$ \\
\hline
\end{tabular}

${ }^{\mathrm{a}}$ Exclusion of pesticide treatments may be unfeasible in botanic gardens

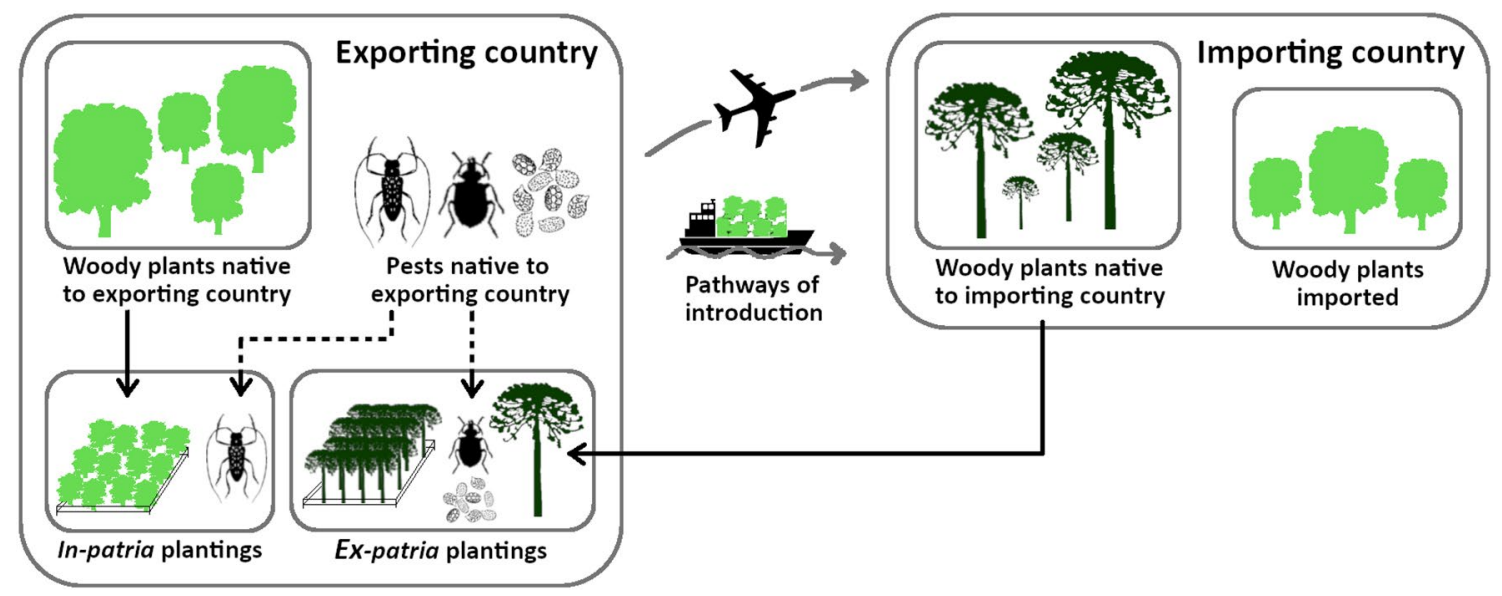

Fig. 1 Schematic representation of sentinel planting types in an exporting country, identified by the origin of the planted trees. The exporting country (left) has a forested area from which pests and pathogens spread to the in-patria and ex-patria plantings (top and bottom in the exporting country). In-patria plantings consist of woody plants native to the exporting country that are surveyed for pests that may enter the pathway of introduction to the importing country, whereas ex-patria plantings consist of woody plants native to the importing country that are surveyed with the aim of identifying damage that may occur if the pests are introduced to the importing country. In-patria plantings typically consist of young woody plants that are planted for this purpose, while ex-patria plantings can either be of young woody plants planted for this purpose (bottom right) or mature trees that were planted for another purpose, such as in botanic gardens (bottom left). More detail can be found in Table 1 
Ex-patria plantings have been used to study the host range of specific, known pests. For example, the bacterium Xylella fastidiosa and its invasive vector, the polyphagous glassywinged sharpshooter, Homalodisca vitripennis (Hemiptera: Cicadellidae) form a pest complex that damages a range of agricultural crops in California. In order to study the susceptibility of perennial New Zealand plant species and the opportunities for biological control of the vector using egg parasites, Groenteman et al. (2015) studied the pests on New Zealand plant species in botanic gardens in California.

Compared to in-patria plantings, which essentially estimate infestation rates of already existing native-to-native associations, Ex-patria plantings are particularly relevant to assess new pest-host associations, such as possible host range shifts by exotic pests to a native host in the importing country that are very difficult to predict (e.g. Woolhouse et al. 2005). In addition to being unpredictable, the level of damage to the host when such new associations occur can be significant. This is illustrated by the fact that many pests and pathogens that were not threatening the health of woody plants in the exporting countries have caused extensive damage in countries where they have been imported. For example, the Asian longhorn beetle, Anoplophora glabripennis (Coleoptera: Buprestidae), was unknown to cause important damage on native tree species in China and Korea, but since it has been introduced in Europe and North America, it became a serious pest of many broadleaf species (Hu et al. 2009). Likely causes for the increased damage in the invaded range include escape from natural enemies that are controlling pest dynamics in the native range (Keane and Crawley 2002), and absence of co-evolution with plant species encountered in the invaded range (Rebek et al. 2008).

The ex-patria planting concept is well represented by botanic gardens, as they often host non-native species from all over the world. The importance of such plantings in the context of non-native species prevention has grown recently and the International Plant Sentinel Network (IPSN) has been launched (Barham et al. 2016) to coordinate surveys and activities carried out at botanic gardens on a global scale.

\section{Benefits and drawbacks}

\section{Age of trees}

The range of pests that can be detected in in-patria and expatria plantings may be affected by various factors, including the age of the surveyed trees, the number of trees per planting and the variety of environments covered by plantings. For example, wood-boring insects such as bark beetles are more likely to attack mature trees, so that sampling and surveying trees in botanic gardens may be more adequate for the detection of such pests. In contrast, foliar pests can often be damaging to young as well as mature woody plants (Roques et al. 2015; Table 1). Monitoring conspecific trees of different ages, including saplings, in the same botanic garden would allow detection of a wider range of pests. Surveys in botanic gardens may have the advantage that the health and the history of the trees are known, although this is not generally the case for older trees, and it should be noted that only specimens that have survived past pest attacks can be examined as the most susceptible trees have already died (Kirichenko and Kenis 2016).

\section{Sampling intensity and pest range}

The range of pests that is detected depends on the frequency of sampling and the sample size. The number of trees of each species in botanic gardens is usually small and the genetic diversity very restricted (Oldfield 2009; Namoff et al. 2010), whereas sentinel plantings that are established for this purpose using young trees allow manipulation of intraspecific genetic diversity and the use of a large number of replicates (Roques et al. 2015). A large number of trees and a variety of habitats may need to be sampled to obtain an almost complete pest inventory, while in most situations only a small subset of all possible pest-plant associations will be effectively identified. However, especially in the case of pathogens, identifying even a small fraction of the organisms that may threaten woody plants in importing countries would prove valuable to pest-risk management programmes and, consequently, prevent new invasions by unknown harmful organisms. An advantage of surveys of botanic gardens, i.e. ex-patria plantings, with both native and exotic plant species may be the presence of both native and exotic pests, the latter introduced when the trees were imported, that would enable detection of a wider range of pests and estimation of their impact. Despite the often large and diverse collections, the number of species from a single genus present in a botanic garden may be limited. To overcome this limitation, the sample size could be increased by collating pest and pathogen incidence on conspecific trees in different arboreta.

\section{Diversity of environmental conditions}

Differences between the environmental conditions in the importing country and those at the place of production, or in the exporting country in general, can affect the outcome of the pest-host combination, hampering the efforts in recognising and detecting the possible pest. Sampling sentinel plantings across multiple locations would therefore not only increase the sample size, but may also allow assessment of environmental conditions that influence pest diversity and the extent of damage caused by the pests. 


\section{Sourcing of planting material}

Initiating sentinel planting studies of both types requires effective collaboration with the Plant Protection Organizations, and may be affected by some administrative matters. In-patria plantings may be relatively easy and inexpensive to initiate, because the planting material can be locally sourced and it is unlikely that restrictions on the planting of native species apply. By contrast, the importation of exotic plants is already restricted in many countries and may increasingly be limited in the future. Therefore, new ex-patria plantings are likely to be made with saplings, grown from seeds collected in the exporting country or from imported propagation material. Many countries have regulations governing the importation and planting of exotic plant species and, even if exemptions for scientific study may be possible, initiating new ex-patria plantings may be more difficult. It is likely be easier to carry out surveys in botanic gardens with established exotic woody plants.

\section{Site management practices}

An additional complexity of surveys in botanic gardens may arise from the use of pesticides. While such management obviously helps keeping the trees healthy, it reduces the abundance of pests and likely suppresses disease symptoms. Hence, only a subset of pests may be detected and the use of pesticides in sentinel plantings should ideally be avoided.

\section{Pest species identification}

It can be challenging to identify the detected organisms. For example, defoliators can be found on sentinel trees at the larval stage and for many groups this would represent a big issue given that keys exist only for certain orders or families and that these are mainly designed for identification of adults. In some cases, it is possible to culture microorganisms or rear immature insects to stages that are easier to identify. Molecular tools may also facilitate the identification, for instance when culturing or rearing proves difficult, or for dead and damaged individuals. However, molecular tools, such as DNA barcoding, may be more useful for identification of some invertebrate groups as a result of differences in the completeness and accuracy of libraries with reference sequences (Roques et al. 2015). In addition, the knowledge of the insect fauna in many parts of the world is incomplete, making identification only possible to higher taxonomic levels than the species. While this obviously limits possibilities for risk assessments for these organisms on a species level, even identification to a higher taxonomic level can provide relevant information for risk assessments (Eschen et al. 2015b). Moreover, because of the limited knowledge about many potential pest species and the potentially large fraction of unidentified organisms found in sentinel plantings (Table 2), it may be preferable to assess risks associated with pathways rather than individual species (Boyd et al. 2013; Brockerhoff and Bulman 2014; Wingfield et al. 2015; Meurisse et al. 2018).

\section{Proof of concept}

Several recent research projects demonstrated how sentinel plantings yield information about harmful organisms (Fig. 1). The boxtree moth, Cydalima perspectalis (Lepidoptera: Crambidae), was shown a successful invader, most likely transported with the trade in living plants from Asia (Kenis et al. 2013). Since its initial finding in Germany in 2007, the moth has spread across Europe and the Black Sea region, where it rapidly became a pest of high concern, killing both ornamental and native box tree species. Although this species was not considered a particularly harmful pest before its dissemination, recent in-patria plantings in China showed it was effective at defoliating native Buxus spp. in its country of origin (Kenis et al. 2018). The studies also highlighted the cases of severe attacks caused by native insects to

Table 2 The utility of sentinel plantings for detecting previously unknown pest-host associations, as revealed by studies of pathogens and arthropods in in-patria and ex-patria plantings

\begin{tabular}{lllllllll}
\hline Planting type & Target pests & Age & Location & \multicolumn{2}{c}{ Associations } & \multicolumn{2}{c}{ Study } \\
\cline { 5 - 7 } & & & & Known (\%) & New (\%) & Unknown (\%) & Total & \\
\hline Ex-patria & Insects & Mature & Russia & 83.6 & 16.4 & 0 & 146 & Kirichenko and Kenis (unpubl.) \\
Ex-patria & Insects & Young & China & 3.1 & 54.2 & 42.7 & 104 & Roques et al. (2015) \\
Ex-patria & Pathogens & Mature & Russia & 56.7 & 43.3 & 0 & 67 & Tomoshevich et al. (2013) \\
Ex-patria & Pathogens & Young & China & 0.5 & 20.9 & 78.6 & 182 & Vettraino et al. (2015) \\
In-patria & Insects & Young & China & 31.6 & 25.2 & 43.2 & 220 & Kenis et al. (2018) \\
In-patria & Pathogens & Young & China & 0 & 17 & 83 & 106 & Vettraino et al. (2017) \\
\hline
\end{tabular}

The unknown taxa, known pest-host associations and new pest-host associations are indicated as a fraction of the total of the recorded taxa in each study. The total number of detected pest-host relationships in each study is also indicated 
non-native plants in botanic gardens. For example, the emerald ash borer, an aggressive East Asian pest which invaded North America and the European part of Russia, killed several trees of the North American Fraxinus pennsylvanica in the botanic garden in the Russian Far East (Yurchenko and Turova 2007; Kirichenko et al. 2011). The emerald ash borer continues to spread westward (Straw et al. 2013) and is likely to affect ash trees in large parts of Europe. These results highlight the value of the sentinel planting concept for the detection of potentially damaging pests and assessment of potential impacts. While both $C$. perspectalis and A. planipennis have established in new areas before the first sentinel planting studies were carried out, these results are still relevant, to inform pest-risk analyses for other countries. Sentinel planting studies have resulted in detection of many more arthropod and fungal pests on saplings of European and Chinese species planted in China (Roques et al. 2015; Vettraino et al. 2015, 2017; Kenis et al. 2018) and on European trees planted in botanic gardens and arboreta in Russia, particularly in Siberia and the Russian Far East, and South Africa (Kirichenko et al. 2011, 2013; Tomoshevich et al. 2013; Kirichenko and Kenis 2016; Paap et al. 2018). These pests are at risk of being introduced on traded plants, thus particular attention should be given to them considering the estimated damage to the trees.

Previous studies also highlighted the scarce knowledge of pests in some countries, as shown by the large fraction of unidentified organisms and significant number of new pest-host combinations among identified pests (Tomoshevich et al. 2013; Roques et al. 2015; Vettraino et al. 2015, 2017; Kenis et al. 2018). Results of Vettraino et al. (2017) have shown that some fungal taxa previously considered low risk, because they were only known as pathogenic on not commonly traded hosts, can also affect additional host that are more commonly traded to Europe. In Siberian botanic gardens, 102 pathogen-host plant associations were recorded, of which 29 were new to science. Among these new associations, 18 appeared noticeably damaging to European woody plants, suggesting that complexes of cryptic pathogen species may occur across the range of their host plants (Tomoshevich et al. 2013). Similarly, analysis of the insects associated with commonly exported Chinese plant species in an in-patria planting revealed that only a minority of the detected insects could be identified to genus or species level and the majority of these had not been recorded in combination with the host (Kenis et al. 2018; Table 2).

These and other studies, however, point at the difficulty to determine the main damaging agent when a complex of pests is discovered (Kirichenko et al. 2011). For example, during surveys in a botanic gardens in the Russian Far East, in the plantations of dying and declining non-native Juglans spp., several insects species damaging leaves, shoots, twigs and stems were sampled in different parts of the season and the development of a canker-like disease was recorded. However, it was impossible to determine the major cause of the decline in the timeframe of the project (Kirichenko et al. 2011). Furthermore, the residence time of the introduced plants and the taxonomic relatedness to native hosts may impact their colonisation by pests (Kirichenko et al. 2013; Kirichenko and Kenis 2016).

\section{Conclusion and recommendations}

In a time of increasing global trade in plants for planting, sentinel plantings could become a key tool for early warning against pests of woody plants. The approach provides relevant information to assist pest-risk analysis and the development of measures to mitigate the risk of introducing new pests of woody plants. However, sentinel plantings can, for reasons related to the cost and practicalities of monitoring, only be successful if based on strong local expertise and close collaboration between scientists and plant protection organisations from the exporting and importing countries. Thus, there is a need for standardised detection and identification methods to reduce costs and facilitate interpretation of the results, as the methods chosen for detection and identification of organisms affects the interpretation of the results and the motivation for risk analysis. Detailed studies may enable scientists to distinguish between pests and other nondamaging organisms collected on a plant, such as arthropods resting on plants without feeding while occasionally ovipositing or trying to feed upon plants, but also to prove that the observed species can develop their full cycle on these plants (Roques et al. 2015). Furthermore, the results of previous studies of sentinel plantings have revealed the relevance of molecular identification of pests, for example using Next Generation Sequencing (Vettraino et al. 2015, 2017), and the urgent need for complete and accurate reference databases in order to identify a larger fraction of the detected organisms. Practical recommendations for the successful management of sentinel plantations and nurseries can be found in Tomoshevich et al. (2013), Roques et al. (2015), Vettraino et al. $(2015,2017)$ and Kenis et al. (2018).

\section{Author contributions}

RE and AS developed the paper. All authors contributed to writing of the manuscript and all read and approved the manuscript.

Acknowledgements This work was supported by COST Action Global Warning (FP1401). RE and MK were supported by CABI with core financial support from its member countries (see http://www.cabi.org/ about-cabi/who-we-work-with/key-donors/). NK was supported by LE STUDIUM $^{\circledR}$ fellowship program, Institute for advanced studies-Loire 
Valley (Orléans, France). The authors thank the reviewers for the thorough reviews and constructive comments that greatly improved the manuscript.

\section{Compliance with ethical standards}

Conflict of interest The authors declare that they have no conflict of interest.

Human and animal rights This article does not contain any studies with human participants or animals performed by any of the authors.

Open Access This article is distributed under the terms of the Creative Commons Attribution 4.0 International License (http://creativeco mmons.org/licenses/by/4.0/), which permits unrestricted use, distribution, and reproduction in any medium, provided you give appropriate credit to the original author(s) and the source, provide a link to the Creative Commons license, and indicate if changes were made.

\section{References}

Aukema JE, McCullough DG, Von Holle B, Liebhold AM, Britton K, Frankel SJ (2010) Historical accumulation of nonindigenous forest pests in the continental United States. Bioscience 60:886-897

Barham E, Sharrock S, Lane C, Baker R (2016) The International Plant Sentinel Network: a tool for Regional and National Plant Protection Organizations. Bull OEPP/EPPO Bull 46:156-162

Boyd IL, Freer-Smith PH, Gilligan CA, Godfray HCJ (2013) The consequence of tree pests and diseases for ecosystem services. Science 342:1235773

Britton K, White P, Kramer A, Hudler G (2010) A new approach to stopping the spread of invasive insects and pathogens: early detection and rapid response via a global network of sentinel plantings. N Z J For Sci 40:109-114

Brockerhoff EG, Bulman L (2014) Biosecurity risks to New Zealand's plantation forests and the rationale for pathway risk management. N Z J For 59:3-8

Brockerhoff EG, Liebhold AM (2017) Ecology of forest insect invasions. Biol Invasion 19:3141-3159

Brockerhoff EG, Liebhold AM, Richardson B, Suckling DM (2010) Eradication of invasive forest insects: concepts, methods, costs and benefits. N Z J For Sci 40(suppl):S117-S135

Carter PCS (1989) Risk assessment and pest detection surveys for exotic pests and diseases which threaten commercial forestry in New Zealand. N Z J For Sci 19:353-374

Dodds KJ, Miller DR (2010) Test of nonhost angiosperm volatiles and verbenone to protect trap trees for Sirex noctilio (Hymenoptera: Siricidae) from attacks by bark beetles (Coleoptera: Scolytidae) in the Northeastern United States. J Econ Entomol 103:2094-2099

Eschen R, Britton K, Brockerhoff E, Burgess T, Dalley V, EpanchinNiell RS, Gupta K, Hardy G, Huang Y, Kenis M, Kimani E, Li H-M, Olsen S, Ormrod R, Otieno W, Sadof C, Tadeu E, Theyse M (2015a) International variation in phytosanitary legislation and regulations governing importation of live plants. Environ Sci Pol 51:228-237

Eschen R, Roques A, Santini A (2015b) Taxonomic dissimilarity in patterns of interception and establishment of alien arthropods, nematodes and pathogens affecting woody plants in Europe. Divers Distrib 21:36-45

Fagan LL, Bithel SL, Dick MA (2008) Systems for identifying invasive threats to New Zealand flora by using overseas plantings of New
Zealand native plants. In: Fourd KJ, Popay AI, Zydenbos SM (eds) Surveillance for biosecurity: pre-border to pest management. New Zealand Plant Protection Society, Christchurch, pp 51-62

Fan JT, Denux O, Courtin C, Bernard A, Javal M, Millar JG, Hanks LM, Roques A (2018) Multicomponent blends for trapping native and exotic longhorn beetles at potential points-of-entry and in forests. J Pest Sci. https://doi.org/10.1007/s10340-018-0997-6

Groenteman R, Forgie SA, Hoddle MS, Ward DF, Goeke DF, Anand N (2015) Assessing invasion threats: novel insect-pathogen-natural enemy associations with native New Zealand plants in southern California. Biol Invasion 17:1299-1305

Gross A, Holdenrieder O, Pautasso M, Queloz V, Sieber TN (2014) Hymenoscyphus pseudoalbidus, the causal agent of European ash dieback. Mol Plant Pathol 15:15-21

Herms DA, McCullough DG (2014) Emerald ash borer invasion of North America: history, biology, ecology, impacts, and management. Annu Rev Entomol 59:13-30

Holmes T, Aukema J, Von Holl B, Liebhold A, Sills E (2009) Economic impacts of invasive species in forests. Ann NY Acad Sci 1162:18-38

Hu J, Angeli S, Schuetz S, Luo Y, Hajek AE (2009) Ecology and management of exotic and endemic Asian longhorned beetle. Agric For Entomol 11(4):359-375

Keane RM, Crawley MJ (2002) Exotic plant invasions and the enemy release hypothesis. Trend Ecol Evol 17:164-170

Kenis M, Rabitsch W, Auger-Rozenberg M-A, Roques A (2007) How can alien species inventories and interception data help us prevent insect invasions? Bull Entomol Res 97:489-502

Kenis M, Nacambo S, Leuthardt FLG, Di Domenico F, Haye T (2013) The box tree moth, Cydalima perspectalis, in Europe: horticultural pest or environmental disaster? Aliens 33:38-41

Kenis M, Li H, Fan J-T, Courtial B, Auger-Rozenberg M-A, Yart A, Eschen R, Roques A (2018) Sentinel nurseries to assess the phytosanitary risks posed by importations of live plants. Sci Rep. https://doi.org/10.1038/s41598-018-29551-y

Kirichenko N, Kenis M (2016) Using a botanical garden to assess factors influencing the colonization of exotic woody plants by phyllophagous insects. Oecologia 182:243-252

Kirichenko NI, Gorokhova SV, Ostrogradsky PG, Kenis M (2011) The colonization of alien woody plants by phyllophagous insects and the decline of alien plants in the arboretum of V.L. Komarov Mountain-taiga Station in Far Eastern Russia. Transactions of Saint Petersburg State Forest Technical Academy, vol 196, pp $54-61$

Kirichenko N, Péré C, Baranchikov Y, Schaffner U, Kenis M (2013) Do alien plants escape from natural enemies of congeneric resident? Yes but not from all. Biol Invasions 15:2105-2113

Kirichenko N, Triberti P, Ohshima I et al (2017) From east to west across the Palearctic: phylogeography of the invasive lime leaf miner Phyllonorycter issikii (Lepidoptera: Gracillariidae) and discovery of a putative new cryptic species in East Asia. PLoS ONE 12(2): e0171104

Liebhold AM, Tobin PC (2006) Growth of newly established alien populations: comparison of North American gypsy moth colonies with invasion theory. Popul Ecol 48:253-262

Liebhold A, Brockerhoff E, Garrett L, Parke J, Britton K (2012) Live plant imports: the major pathway for the forest insect and pathogen invasions of the US. Front Ecol Environ 10:135-143

Marshall JM, Storer AJ, Fraser I, Beachy JA, Mastro VC (2009) Effectiveness of differing trap types for the detection of Emerald Ash Borer (Coleoptera: Buprestidae). Environ Entomol 38:1226-1234

McCullough DG, Poland TM, Cappaert D (2009) Attraction of the emerald ash borer to ash trees stressed by girdling, herbicide treatment, or wounding. Can J For Res 39:1331-1345

Meurisse N, Rassati D, Hurley BP et al (2018) Common pathways by which non-native forest insects move internationally 
and domestically. J Pest Sci. https://doi.org/10.1007/s1034 0-018-0990-0

Migliorini D, Ghelardini L, Tondini E, Luchi N, Santini A (2015) The potential of symptomless potted plants for carrying invasive soilborne plant pathogens. Divers Distrib 21:1218-1229

Namoff S, Husby CE, Fransisco-Ortega J, Noblick LR, Lewis CE, Griffith MP (2010) How well does a botanical garden collection of a rare palm capture the genetic variation in a wild population? Biol Conserv 143:1110-1117

Oldfield SF (2009) Botanic gardens and the conservation of tree species. Trends Plants Sci. 14:581-583

Paap T, Burgess T, Wingfield MJ (2017) Urban trees: bridge-heads for forest pest invasions and sentinels for early detection. Biol Invasions 19:3515-3526

Paap T, De Beer ZW, Migliorini D, Nel WJ, Wingfield MJ (2018) The polyphagous shot hole borer (PSHB) and its fungal symbiont Fusarium euwallaceae: a new invasion in South Africa. Australas Plant Pathol 47:231-237

Poland TM, McCullough DG (2006) Emerald Ash Borer: Invasion of the urban forest and the threat to North America's ash resource. J For 104:118-124

Poland TM, Rassati D (2018) Improved biosecurity surveillance of non-native forest insects: a review of current methods. J Pest Sci. https://doi.org/10.1007/s10340-018-1004-y

Rebek EJ, Herms DA, Smitley DR (2008) Interspecific variation in resistance to emerald ash borer (Coleoptera: Buprestidae) among North American and Asian ash (Fraxinus spp.). Environ Entomol $37: 242-246$

Roques A, Rabitsch W, Rasplus J-Y, Lopez-Vaamonde C, Nentwig W, Kenis M (2009) Alien terrestrial invertebrates of Europe. In: DAISIE (ed) Handbook of alien species in Europe. Springer, Berlin, pp 63-79

Roques A, Fan J, Courtial B, Zhang Y, Yart A, Auger-Rozenberg M-A, Denux O, Kenis M, Baker R, Sun J (2015) Planting sentinel European trees in eastern Asia as a novel method to identify potential insect pest invaders. PLoS ONE 10:e0120864

Santini A, Ghelardini L, De Pace C, Desprez-Loustau M-L, Capretti P, Chandelier A, Cech T, Chira D, Diamandis S, Gaitniekis T, Hantula J, Holdenrieder O, Jankovsky L, Jung T, Jurc D, Kirisits T, Kunca A, Lygis V, Malecka M, Marcais B, Schmitz S, Schumacher J, Solheim H, Solla A, Szabo I, Tsopelas P, Vannini A, Vettraino A, Webber J, Woodward S, Stenlid J (2013) Biogeographical patterns and determinants of invasion by forest pathogens in Europe. New Phytol 197:238-250

Seebens A, Blackburn TM, Dyer EE, Genovesi P, Hulme PE et al (2018) The global rise in emerging alien species results from increased accessibility of new source pools. Proc Natl Acad Sci USA 115:E2264-E2273
Smith RM, Baker RHA, Collins DW, Korycinska A, Malumphy CP, Ostojá-Starzewski JC, Prior T, Pye D, Reid S (2018) Recent trends in non-native, invertebrate, plant pest establishments in Great Britain, accounting for time lags in reporting. Agric For Entomol. https://doi.org/10.1111/afe.12282

Straw NA, Williams DT, Kulinich O, Gninenko YI (2013) Distribution, impact and rate of spread of emerald ash borer Agrilus planipennis (Coleoptera: Buprestidae) in the Moscow region of Russia. Forestry 86:515-522

Sweeney J, Anderson RS, Webster RP, Nevill R (2012) First records of Orchestes fagi (L.) (Coleoptera: Curculionidae: Curculioninae) in North America, with a checklist of the North American Ramphini. Coleopts Bull 66:297-304

Thu PQ, Dell B, Burgess TI (2009) Susceptibility of 18 eucalypt species to the gall wasp Leptocybe invasa in the nursery and young plantations in Vietnam. ScienceAsia 35:113-117

Tomoshevich M, Kirichenko N, Holmes K, Kenis M (2013) Foliar fungal pathogens of European woody plants in Siberia: an early warning of potential threats? For Pathol 43:345-359

Vettraino A, Roques A, Yart A, Fan J, Sun J, Vannini A (2015) Sentinel trees as a tool to forecast invasions of alien plant pathogens. PLoS ONE 10:e0120571

Vettraino AM, Li H-M, Eschen R, Morales-Rodriguez C, Vannini A (2017) The sentinel tree nursery as an early warning system for pathway risk assessment: Fungal pathogens associated with Chinese woody plants commonly shipped to Europe. PLoS ONE 12(11): 0188800

Werres S, Marwitz R, Man in't Veld WA, De Cock AWAM, Bonants PJM, De Weerdt M, Themann K, Ilieva E, Baayen RP (2001) Phytophthora ramorum sp. nov., a new pathogen on Rhododendron and Viburnum. Mol Res 105:1155-1165

Wingfield MJ, Brockerhoff EG, Wingfield BD, Slippers B (2015) Planted forest health: the need for a global strategy. Science 349:832-836

Woolhouse MEJ, Haydon DT, Antia R (2005) Emerging pathogens: the epidemiology and evolution of species jumps. Trends Ecol Evol 20:238-244

Wylie FR, Griffiths M, King J (2008) Development of hazard site surveillance programs for forest invasive species: a case study from Brisbane, Australia. Aust For 71:229-235

Yurchenko GI, Turova GI (2007) To the spread and ecology of the emerald ash borer Agrilus planipennis Fairmair in the Far East of Russia. In: Bulletin of the Standing Committee on Biological Protection of the Forest of the IOBC-EPRS, vol 7. VNIILM, Pushkino, pp 125-130 